\title{
EXERGY AND EMERGY: COMPLEMENTARY TOOLS FOR ASSESSING THE ENVIRONMENTAL SUSTAINABILITY USE OF BIOSOLIDS GENERATED IN WASTEWATER-TREATMENT PLANT FOR ENERGY- PRODUCTION
}

\author{
Natalia A. Cano ${ }^{\mathrm{a}, *, \odot, ~ S a n t i a g o ~ C e ́ s p e d e s-Z u l u a g a ~}{ }^{\mathrm{a}}$, Camilo Guerrero-Martin ${ }^{\mathrm{b}, \mathrm{c}}$ and Darío Gallego ${ }^{\mathrm{a}}$ \\ aUniversidad Nacional de Colombia Sede Medellín, Medellín 050041, Colombia \\ bFundación Universidad de América, Bogotá, Colombia \\ ${ }^{\mathrm{c} C e n t r o ~ d e ~ E c o n o m i a ~ E n e r g e ́ t i c a ~ e ~ A m b i e n t a l, ~ U n i v e r s i d a d e ~ F e d e r a l ~ D o ~ R i o ~ d e ~ J a n e i r o, ~ 21941-914, ~ R i o ~ d e ~ J a n e i r o ~-~ R J, ~ B r a s i l ~}$
}

Recebido em 07/03/2021; aceito em 06/07/2021; publicado na web em 10/08/2021

\begin{abstract}
Taking advantage of the energy contained in the biosolids generated in a wastewater treatment plant (WWTP) is one of the processes of greatest interest due to the opportunity to obtain an energy resources from a waste. The aim of this research was to analyze the environmental sustainability use of biosolids generated in a wastewater-treatment plant for energy-production by fluidized-bed gasification under exergy analysis. The energy-production system was based on previous studies of sustainable-emergy alternatives using biosolids. Sustainability of the process was evaluated by identifying stages in the energy-production system (from drying application to electricity generation) where it is possible to reduce useful energy losses as well as identifying the value of waste streams within the system through exergy analysis. It was illustrated the destroyed exergy and the efficiency by stage and by product in order to assess the effects of inefficiencies in the process sustainability. The mixture of biosolids with coal was identified as a highly sustainable stage of the process, as it presents the highest index of exergy sustainability (0.99), in contrast to the stages of energytransformation (turbine) and gas-cleaning, which efficiencies are 0.17 and 0.4, respectively. Energy-transformation and gas-cleaning stages are of interest in terms of an improved energy recovery process, making it more efficient by applying new technologies and/ or using the waste streams that have high energy potentials.
\end{abstract}

Keyword: biosolids; energy analysis; exergy analysis; sustainability; gasification.

\section{INTRODUCTION}

Currently, in the city of Medellín (Colombia) being produced 127.787 wet tonnes of biosolids ${ }^{1}$ because of the increase in the number of households connected to the new wastewater-treatment system and of the greater content of organic matter in industrial waste effluents. Correspondingly, an exponential increase is predicted for use as an energy source, according to the international guidelines for generation of alternative energy from industrial waste..$^{2-4}$ Consequently, there is a need to evaluate the sustainability of biosolids-treatment processes generated in a wastewater-treatment plant (WWTP) for energy production.

Some research have demonstrated the potential of biosolid generated from a WWTP to produce energy in different ways; $;{ }^{5,6}$ as an example; the anaerobic processes and the hydrothermal carbonization of biosolids have been used to help offset the electricity consumption of a WWTP. ${ }^{7}$ In this way, the coupling between wastewater treatment and energy production could help to meet the needs of the specific water treatment industry, with a view to diversifying the energy matrix by taking advantage of the biosolids generated in the operating process.

Sustainability is a paradigm on which all future policies must be based. Therefore, conceptual tools have been developed to quantify it based on ecological and economic indexes, which separately estimate a numerical value in a fragmented analysis. ${ }^{8}$ To achieve sustainability in different production systems, sustainable energy resources and the efficient use of their waste are required. ${ }^{910}$ Hence, it is necessary to develop and apply methodological tools that can quantitatively integrate both ecological and economic dimensions to evaluate, compare, and account for the environmental impacts in a process. ${ }^{11}$ Methodologies that have been used for this purpose are the exergy and

*e-mail: nacanol@unal.edu.co emergy analyses, these allow the minimization of negative impacts on the ecosystem and foster economic profitability by comparing efficiency of productive systems and technological development. In addition, this type of methodologies allows evaluating the use of energy resources and the environmental impact generated from utilization technologies.

Exergy analysis is a method based on the second law of thermodynamics, provides an alternative process comparison and allows design improvement and optimization in energy systems. ${ }^{12}$ For instance, Niembro et al. ${ }^{13}$ concluded that environmental degradation is one of the problems associated with exergy losses (destruction and disposal of available energy). Thus, this study is related to an environmental analysis, where the lost exergy is attributed to inherent irreversibility of the process and a low use of available resources. On the other hand, evaluating energy production systems, Wang et al. ${ }^{14}$ used exergy analysis to evaluate the use of waste energy through organic Rankine cycles. This research evaluates the environmental and economic impacts of the cycle operation, comparing different types of refrigerants and choosing the one with the best performance. Moreover, exergy analysis has been used as a tool to reduce energy consumption in industries such as compressors, where the analysis is complemented with sustainability and emissions analysis. ${ }^{15}$ In addition, the exergy concept has been used in other processes such as biomass conversion, where the optimization of the process is sought, ${ }^{16}$ and the comparison of processes that use different sources of energy for the same purpose, such as fuels for boilers. ${ }^{17}$ Finally, the exergy tool has also been used to evaluate the sustainability of non-industrial sectors, as in the research presented by Chowdhuty et al. ${ }^{18}$ where the sustainability of the residential sector in Bangladesh is evaluated through exergy analysis.

On the other hand, the emergy analysis is an assessment tool to evaluate sustainability through the accounting of resources 
through a unit as the energy from the sun (solar energy - main source of energy on earth). This methodology was proposed by H.T. Odum $^{19}$ and has been used in different research to account for the environmental impact allowing to identify sustainable processes through multiple indexes that relate the nature of resources used with the performance of a process. Emergy analysis is an integrated evaluation of economic, ecological, technical and energy systems. Emergy analysis has been successfully applied to systems of different scales and economic sectors ${ }^{20}$ which include: regional sustainability, ${ }^{21}$ restoration of ecosystems, ${ }^{19-23}$ evaluation of building, ${ }^{23}$ and evaluation of wastewater technology, ${ }^{24,25}$ mainly in order to use it as a tool for environmental decision-making, through emergy indexes for the evaluation of sustainability whose theory lies in the discretization of renewable, non-renewable and imported resources, which means that the emergy of a process is based on the environmental aspect (ecosystem services), energy (contribution of materials) and economic (investment in inputs such as human labor), covering the three dimensions of the concept of sustainability, understood as the compatibility between the energy, economic and environmental dimensions; that is, the highest economic performance that a process limited to an acceptable environmental load can achieve. ${ }^{1}$

Regarding the use of exergy analysis in the processes carried out in WWTP, different research have been carried out. Hellström et $a l .{ }^{26}$ exemplifies the use of exergy analysis to estimate resource consumption in a WWTP located in Sweden. In this study, it was demonstrated the energy potential of the biosolids generated. A similar investigation but directed to the thermodynamic efficiency of a WWTP was carried out by Fitzsimons et al. ${ }^{27}$ where the energy potential of the streams involved in the process of a WWTP is calculated., Shao et al. ${ }^{28}$ applied the exergy analysis to evaluate the types of resources used in a WWTP located in China in order to evaluate the sustainability of the process and present the energy analysis as a methodology applicable to other processes. Considering different processes that occur within a WWTP, Ozdil et al. ${ }^{29}$ evaluated the use of biogas generated through the process of the WWTP located in Turkey for the generation of internal energy, this study was complemented with an exergoeconomic analysis, obtaining costs per unit of electrical energy produced. Mora et al. ${ }^{30}$ evaluated the sustainability of a WWTP located in Brazil through the application of different indexes based on exergy analysis. Finally, one of the investigations where the use of exergy analysis has been most demonstrated for the valuation of the WWTP process streams was carried out by Muñoz et al. ${ }^{31}$ In this research, the energy degradation of water from the source in a river to the outlet of a WWTP is evaluated, where each subsystem of the global process is evaluated, comparing the efficiency of each one and evaluating the available energy of the streams involved in each stage supply chain.

To date, research addressing both exergy and emergy as well as complementary analyse $\mathrm{s}^{20,32-34}$ has not applied such concepts to the use of sludge produced in WWTPs for energy production. Several studies present the application of these methodologies to biodiesel-production systems,,${ }^{35}$ cropping systems, ${ }^{33}$ and energy-production systems ${ }^{34}$ and discuss application mode and how exergy and emergy methods can be mutually complementary. These studies conclude that the two methods, in an extended sense, are compatible; it is handled different types of analysis boundaries, which allow evaluating the process from different perspectives. ${ }^{34,36}$ These approaches let identifying sustainable (or unsustainable) characteristics from the elements involved in the processes that originate the biosolids but not how sustainable the management of them is, which is the main subject of this contribution. A sustainable analysis of biosolids utilization is a forward step in developing a more sustainable process of wastewater treatment that has not yet been created.
This research shows the use of emergy and exergy analysis to evaluate the sustainability of energy production from biomass generated in a WWTP. The waste from WWTP process is valued as a source of energy. Emergy analysis allow to account for evaluating the sustainability of the process in terms of the quantity and quality of resources used. Alternatively, exergy analysis is used to account for the environmental burden of the generation of a product or service by quantifying the loss of available energy as one of the negative effects related to resource demand.

As a complement to the emergy analysis developed by Cano et al. ${ }^{1}$ the current research addresses the application of exergy analysis to the most sustainable alternative for the use of the biosolids generated in a WWTP, in terms of emergy analysis, by proposing the most appropriate processing method from an energy point of view. Biological treatment of wastewater remains unfinished if it is not coupled with an alternative sustainable use of discharges, including obtained biosolids, to stop being just processed waste and instead to become a raw material as a usable energy source. ${ }^{1}$ This is done by applying the following methodology: (1) First, a comparison between both methods is made in order to determine the limits of analysis, advantages and disadvantages of each method and points they complement each other within a process sustainability analysis. (2) Then, emergy analysis results from the energy recovery system through gasification developed by Cano et al. ${ }^{1}$ are explained; (3) after the application of exergy analysis, it is calculated the respective exergy-environmental sustainability indexes, making a comparison in each stage of the process, and concluding which is more sustainable; (4) and from the results of the exergy analysis, infer a better performance of the process.

\section{EXPERIMENTAL}

\section{Use of biosolids generates in wastewater-treatment plant by gasification}

In Colombia as in most of some countries around the world, domestic wastewater treatment plant is mostly performed using aerobic processes, followed by an anaerobic stabilization and biosolids are generated. These biosolids have an important organic component that can be used to reduce energy cost or to produce energy. This situation makes biosolids an energy source. ${ }^{37}$ Cano et al. ${ }^{1}$ initially considered it to be a renewable-energy source, but it can be considered non-renewable given that the renewable or non-renewable nature of a source depends intrinsically on the consumption speed with respect to the generation speed. Table 1 shows the composition of the biosolid considered in this research. For more information regarding biosolids and the characterization of the process, it is recommended to review the research carried out by Cano et al. ${ }^{1}$

Table 1. characterization of biosolids obtained from WWTP

\begin{tabular}{cc}
\hline Component & Mass fraction \\
\hline Solids & 0.366 \\
C & 0.120 \\
H & 0.056 \\
P & 0.026 \\
N & 0.016 \\
S & 0.001 \\
Cl & 0.001 \\
Heavy metals & 0.003 \\
Ash & 0.120
\end{tabular}

Data provided by the studied of Cano-Londoño et al. ${ }^{1}$ 
Gasification is a thermochemical process in which biosolids are processed to obtain a gas with a very low calorific value that is of great interest to different industries as the precursor of different components; a clean-fuel, it is a gas rich in methane and hydrogen. ${ }^{38,39}$ Waste from the process is only ash, which can be deposited in landfills. It has a great advantage over other thermal processes due to the low generation of greenhouse gases, and it is self-sustaining, in terms of energy. ${ }^{39} \mathrm{~A}$ trend in the field of biosolids management is to transform them into usable energy and thus to reduce environmental problems, positioning itself as one of the most promising technologies. ${ }^{2,3}$

A disadvantage of gasification is that some cases require the removal of tars, which translates into higher operating costs. However, Schowanek et al. ${ }^{40}$ demonstrated potential evolution of alternative uses of biosolids in the European Union; a clear trend positioning heat generation was predicted as the most viable solution from environmental, economic, and practical points of view with $59 \%$ use compared to other alternatives focused in agriculture.

In this research, biosolids are mixed with $10 \%$ carbon into gasification process in order to improve the calorific power of sludge by $6 \%$ with respect to the overall process. The advantages of using coal as a fluidizer reportedly can be extended in comparison with others used commercially. ${ }^{1,41}$ With a $10 \%$ carbon component in the total biosolids mixture implemented, the ratio of moles of hydrogen to carbon is guaranteed to be within 1.6-2.3, thereby ensuring the reduction of tars with a high $\mathrm{H}_{2}$ and $\mathrm{CO}$ content. ${ }^{41}$

\section{Emergy and exergy analyses as tools for sustainability assessment}

In this section, the concepts of emergy and exergy are defined. Also, it is discussed their relation with environmental sustainability, and it is indicated how the exergy analysis complements the process previously analyzed through emergy analysis by Cano et al. ${ }^{1}$

\section{Emergy analysis}

The emergy of a process is the sum of the renewable (R), nonrenewable $(\mathrm{N})$, and imported $(\mathrm{F})$ resources in emergy units $(\mathrm{E}(\mathrm{R})$, $\mathrm{E}(\mathrm{N}), \mathrm{E}(\mathrm{F}))$ as is showed in the Eq.1, and each of these is the sum of all the component inputs ( $\mathrm{R}$ or $\mathrm{N}$ or $\mathrm{F}$ given the case) converted to emergy units as it is presented in Equation 2-Equation 3:42

$$
\begin{gathered}
E=E_{(R)}+E_{(N)}+E_{(F)} \\
E_{(R)}=\sum_{i} E_{i(R)} \times U E V_{i(R)} \\
E_{(N)}=\sum_{i} E_{i(N)} \times U E V_{i(N)} \\
E_{(F)}=\sum_{i} E_{i(F)} \times U E V_{i(F)}
\end{gathered}
$$

where: $\mathrm{E}$ is the total emergy; $\mathrm{E}_{\mathrm{i}}$ is the available energy separated into $\mathrm{R}, \mathrm{N}$ and $\mathrm{F}$; $\mathrm{UEV}_{\mathrm{i}}$ is the Unit Emergy Value of the ith input for each of R, N and F. Values of UEV represent the ratio of solar energy embodied in a product or process in terms of solar equivalent joules (seJ) per joule (seJ/J), or per kilogram (seJ/kg), or per money earned $(\mathrm{seJ} / \$) .{ }^{19}$

The procedure of emergy synthesis does not focus on trying to reduce different material, energy, monetary components, etc. to solar energy as a value of physical change; rather, it interjects both material and energy elements into the calculation of work done by nature to generate a specific system or component, measured in solar energy equivalents to correspond to the definition of emergy. ${ }^{19}$
Emergy analysis is one of the few evaluation methods that recognizes economic and natural systems as well as their interactions within a common methodology, making the analysis from a macro (less detail) to a micro (more detail) scale, taking into account the time scale or memory of services used. ${ }^{43}$

Emergy indexes ${ }^{19}$ can be used to support the use of emergy accounting in sustainability assessments, in particular comparisons of alternative approaches to production system. ${ }^{44}$ The Environmental Loading Ratio (ELR) refers to the ratio of non-renewable plus imported resources to renewable resources, Equation 5. ELR $<2$ indicates that the production process has a low environmental impact; ELR $>10$ indicates a high environmental impact; and $2<$ ELR $<10$ indicates a moderate impact. ${ }^{42,45}$

$$
E L R=\frac{E_{(N)}+E_{(F)}}{E_{(R)}}
$$

The Emergy Yield Ratio (EYR) refers to the ratio of total emergy to imported resources, Equation 6 . EYR $<5$ indicates that large amounts of secondary resources are used in the process; EYR $<2$ indicates a low contribution of primary resources; and EYR $>5$ indicates a dominant use of primary resources..$^{42,46}$

$$
E Y R=\frac{E_{(R)}+E_{(N)}+E_{(F)}}{E_{(F)}}
$$

The Emergy Sustainability Index (ESI) is the ratio ELR: EYR. When $\mathrm{ESI}<1$, the process and products are not considered sustainable in the long term. ${ }^{47} 1<\mathrm{ESI}<5$ is considered sustainable in the midterm. ESI $>5$ is considered sustainable in the mid- and long-terms. ${ }^{45}$

This analysis has been applied to the evaluation of different production systems, such as wastewater technology $y^{1,24,25}$ by which it was concluded that wastewater-treatment remains unfinished if the system does not include the final disposal of the generated waste. Such final disposal, as will be discussed below, has an energy potential as a sustainable use. According to Cano et al., ${ }^{1}$ the sustainability of subjecting biosolids to thermal treatment by means of emergy analysis is supported by the fact that the process presents the highest economic performance with the least environmental burden.

\section{Exergy analysis}

The thermodynamic principles for energy evaluation of a process are the conservation of energy (first law of thermodynamics), which quantifies energy in a process, and the second law of thermodynamics, which characterizes energy somewhat qualitatively and also indicates how such assessment degrades during spontaneous processes, respectively. ${ }^{48}$ These principles show the direction a system may take or transformation it may undergo when applying a process to it.

The combination of the two thermodynamic principles allows the formulation of exergy analysis, which focuses on calculating the availability of each stream involved in a process to perform work. Also, as a consequence of the second law of thermodynamics, this availability decreases due to destroyed exergy, which explains the irreversibility and describes the quantification of the ecological or environmental effect of a process. ${ }^{9}$ Accordingly, the definition of exergy as a non-conservative thermodynamic property appears: It is the measure of the maximum amount of work that can be extracted when a system is brought into balance with its surroundings. ${ }^{49}$ The application of exergy analysis allows the study of the exergy streams involved in a process; this property decreases owing to the irreversibility present in a system, and the reduction is expressed 
by destroyed exergy. Exergy accounting is done by the following expression for a system in steady-state:

$$
E_{x i n}-E_{x o u t}=E_{x d}
$$

where $E_{\text {xin }}$ and $E_{x o u t}$ are exergy input and output of the system, respectively, by any transfer mechanism (mass, heat, and work) and $E_{x d}$ is exergy destroyed.

In order to deduce an expression that allows the exergy analysis to be carried out, it is necessary to clarify that it can be transferred through different mechanisms as same as energy. The mechanisms are: exergy transfer by mass, heat flow and work. ${ }^{49}$ Another contribution in the exergy analysis is the chemical exergy of a substance, which is the maximum useful work that can be obtained by the process of chemical equilibrium of a substance with the environment. ${ }^{50}$

- Exergy transfer by work: As mentioned previously, exergy analysis is an analysis based on the second law of thermodynamics, therefore it deals with energy quality, as work is the form of energy with the highest quality, the exergy transferred by work is work itself as shown in the Equation 8.

$$
E_{X W}=W
$$

- Exergy transfer by heat: It is known that all work can be converted into heat, but not all heat can be transformed into work (Heat is a more "disorganized" form of energy than work). This transformation has a limit which is dictated by the maximum efficiency that a thermal machine can have between two sources of energy at $\mathrm{T}$ and $\mathrm{T}_{\mathrm{o}}$ knowing as the Carnot efficiency. The amount of exergy that can be transferred by heat is expressed through Equation 9 .

$$
E_{X Q}=\left(1-\frac{T_{o}}{T}\right) Q
$$

where $\mathrm{Q}$ is the amount of heat that is transferred to the system, $\mathrm{T}$ the temperature of the system and $\mathrm{T}_{\mathrm{o}}$ the temperature of the dead state or temperature of the surroundings.

- Exergy transfer by mass: All the systems analyzed in this study are open systems which exchange mass with the surroundings, this mass contain exergy because its properties differ from those of the dead state, the amount of exergy can be calculated from the next expression Equation 10.

$$
E_{X f m}=h-h_{0}-T_{0}\left(s-s_{0}\right)+\frac{C^{2}}{2}+g z
$$

where the subscript "o" indicates that the property is calculated in the dead state. The expression shown above is the physical exergy of a stream of a substance entering or leaving the analysis system.

For the calculation of chemical exergy it is necessary to know the nature and composition of the studied substance, all calculations can be developed based on the principle that the substance will react with the components of the environment at $T_{0}$ and $P_{o}$ to produce the components of the environment. ${ }^{50}$ In the case of biomass, the chemical exergy can be calculated by means of correlations that relate the lower heating value (LHV) or net calorific value and the compositions of the substances contained in the biomass. ${ }^{51}$ As the biomass is treated as a solid fuel, an expression to calculate the chemical exergy is the following Equation $11 .^{52}$

$$
E_{X q m}=\beta L H V
$$

where $\beta$ is a coefficient that relates the chemical exergy and the net calorific value of the compound. The coefficient $\beta$ has multiple expressions that depend on the type of compound and the phase. For biomass treated in this study the following expression will be used for $\beta$ Equation 12:52,53

$$
\beta=\frac{1.042+0.2160\left(\frac{w_{H 2}}{w_{c}}\right)-0.2499\left(\frac{w_{O 2}}{w_{c}}\right)\left[1+0.7884\left(\frac{w_{H 2}}{w_{c}}\right)\right]+0.045\left(\frac{w_{N 2}}{w_{c}}\right)}{1-0.3035\left(\frac{w_{O 2}}{w_{c}}\right)}
$$

To calculate the net calorific value, it is calculated by means of the following correlations. ${ }^{54}$

$$
\begin{gathered}
H H V=337.3 \cdot C+1418.9 \cdot\left(H-\frac{O}{8}\right)+93.1 \cdot S+23.2 \cdot N \\
L H V=H H V-25 \cdot\left[9 \cdot\left(H-\frac{O}{8}\right)+W\right]
\end{gathered}
$$

where $\mathrm{HHV}$ is the higher calorific value and $\mathrm{C}, \mathrm{H}, \mathrm{O}, \mathrm{N}$ and $\mathrm{W}$ are the percentages of carbon, hydrogen, oxygen, nitrogen and water on a wet basis in the biomass.

For the calculation of the chemical exergy of a mixture of components it is important to count the losses caused by such a mixture (irreversibility), the chemical exergy is calculated with the following expression Equation 15..$^{52,55}$

$$
E_{\text {Xqmix }}=\sum_{i}^{n} x_{i} E_{x q o i}+R T_{o} \sum_{i}^{n} x_{i} \ln x_{i}
$$

where $E_{x q o i}$ s the standard chemical exergy of component $\mathrm{i}$ and is tabulated in texts such as ${ }^{50,52}$ and $x_{i}$ is the fraction of the component $\mathrm{i}$ in the mixture. For this investigation, the standard chemical exergy of the components used are shown in the Table 2.

Table 2. Standard chemical exergy of components used in research

\begin{tabular}{cc}
\hline Component & Standard chemical exergy $(\mathrm{kJ} / \mathrm{kmol})$ \\
\hline Steam & 9500 \\
water & 45 \\
$\mathrm{C}$ & 404590 \\
$\mathrm{H}_{2}$ & 235250 \\
$\mathrm{O}_{2}$ & 3950 \\
$\mathrm{~N}_{2}$ & 640 \\
$\mathrm{~S}$ & 598160 \\
Isopropyl & 2007820 \\
\hline
\end{tabular}

Through such analysis, it is possible to identify critical points in a system, such as those where the greatest destroyed exergy is produced or where it is possible to increase efficiencies by changing process conditions. With this type of analysis, waste or emissions are treated as important sources of energy. According to Dincer \& Rosen (2008), ${ }^{9}$ to increase sustainability in the use of energy, we must focus not only on energy losses, but also on the reduction of energy quality losses.

Based on the calculation of exergy indexes, environmental impact is related to exergy efficiency as well as different environmental changes that may occur due to the operation of a process to make it more sustainable. ${ }^{56}$ The methodology provides strategies that allow a more rational use of energy resources and ensure energy supply along with maintaining the environmental quality of systems. ${ }^{57}$ In other words, the goal of exergy analysis as a tool for sustainability assessment is the minimization of entropy generation along across supply chain. 
Various indexes are used to quantify the impact of streams and processes in exergy analysis. These allow the different stages to be compared, classified, and arranged into a hierarchy within an analyzed system. The indexes used in this work are discussed below. Exergy renewability index ${ }^{22} \alpha$ is quantified as

$$
\alpha=\sum_{i} \frac{B r_{i}}{B r_{i}+B n_{r i}}
$$

where $B r_{i}$ is exergy consumed from transformation technology that uses renewable carriers, and $B n_{r i}$ is exergy consumed from transformation technology that uses non-renewable carriers. This index can have values in the range $0-1$, where 1 is the most desired value, as it would mean that exergy consumed in the system comes entirely from renewable sources, and where 0 would indicate that exergy consumed in the system is obtained entirely from non-renewable sources. ${ }^{22}$

Exergy efficiency of second law is expressed as

$$
\tau=\frac{E x_{\text {prod }}}{E x_{\text {in }}}
$$

where $E x_{\text {prod }}$ is exergy produced by the system, and $E x_{i n}$ is total input exergy.

Exergy efficiency of the product is defined as

$$
\beta_{i}=\frac{E_{\text {prod }-i}}{E_{\text {in }}}
$$

where $E_{\text {prod-i }}$ is the quantity of exergy that the product contains, and $E_{m}$ is the input energy in a specific stage supply chain.

As previously discussed, the relation between exergy and environment provides knowledge of environmental impacts associated with the implementation of a process. Specifically, the ratio between process input and process exergy destroyed is a sign of the degree of degradation that translates into environmental impacts. When useful exergy of a system approaches $100 \%$, environmental impacts approach zero because no destroyed exergy is produced. Ojeda et al. ${ }^{55}$ defined this index with respect to exergy efficiency as

$$
S I=\frac{1}{D_{p}}
$$

where $D_{p}$ is the depletion number, expressed as

$$
D_{p}=\frac{E_{D}}{E_{\text {in }}}
$$

where $E_{D}$ is exergy destroyed in the system (irreversibility), and $E_{\text {in }}$ is input exergy to the system.

Unlike exergy analysis, emergy analysis applied by Cano et al. ${ }^{1}$ took into account discretized ecological resources (renewable, nonrenewable, and imported); that is, the limit of analysis was expanded to consider the input of primary energy and all types of resources in the process. However, in this study the limits of analysis are restricted to direct industrial-process resources.

\section{Exergy analysis to complement emergy analysis for evaluation of processes}

Current controversy between the exergy and emergy community for the assessment of the sustainability of development projects lies in calculating the emergy based on the exergy (energy available) and not based on energy as has been done.
The term "emergy" refers to the "energy memory"; this means that it is a quantification of the energy needed to produce a service or product. ${ }^{1}$ In all transformation processes from solar energy to the product of interest, the laws of thermodynamics govern a series of transformations during each of which there is a loss of energy available to do work (energy quality).

A relation between exergy and emergy can be deduced from the above: Emergy is based on the general theory of systems and the principle of maximum power, whereas exergy is a purely thermodynamic concept with ecological and environmental applications. According to emergy principles, to obtain a product with a higher energy quality, a greater quantity of energy must be inverted, and energy is dissipated in the process. In this way, the energy is concentrated, thereby increasing the quality and decreasing the quantity. On the other hand, exergy analysis, being based on the second law of thermodynamics, involves energy degradation with increasing entropy while a defined amount of energy undergoes transformation to obtain a product (mass flow and heat-work interactions between system and surroundings), which has a lower exergy than the sum of all the exergy needed to obtain it, owing to exergy destroyed. Then, to obtain a product with a higher energy quality, energy must be dissipated. Thus, the first relation between the two quantities is the energy hierarchy based on quality.

When analyzing the transformation stages from solar energy to a particular product, the first and second law of thermodynamics and exergy analysis can be applied to each stage. In this way, emergy can be expressed both as a function of the exergy and energy.

Exergy and emergy analyses of a system differ (Table 3).

Table 3. Comparison between exergy and emergy

\begin{tabular}{ll}
\hline \multicolumn{1}{c}{ Exergy } & \multicolumn{1}{c}{ Emergy } \\
\hline $\begin{array}{l}\text { Recognizes energy quality due to } \\
\text { energy-transfer mechanisms. }\end{array}$ & $\begin{array}{l}\text { Recognizes difference in energy } \\
\text { quality from different sources. }\end{array}$ \\
\hline $\begin{array}{l}\text { Represents only mass and energy } \\
\text { flows. }\end{array}$ & $\begin{array}{l}\text { Can account for all flows } \\
\text { (environmental and social) involved } \\
\text { in process. }\end{array}$ \\
\hline $\begin{array}{l}\text { Deals with issue of energy quality } \\
\text { through entropy property (hierarchy } \\
\text { of energy). }\end{array}$ & $\begin{array}{l}\text { Deals with issue of energy quality by } \\
\text { means of transformations (hierarchy } \\
\text { of energy). }\end{array}$ \\
\hline $\begin{array}{l}\text { Does not consider time variable. } \\
\text { Function of system and surroundings. }\end{array}$ & $\begin{array}{l}\text { Function of time in which energy } \\
\text { was used to have available resource } \\
\text { (energy memory). }\end{array}$ \\
\hline $\begin{array}{l}\text { Energy method that allows } \\
\text { quantitative measurements for } \\
\text { decision-making. }\end{array}$ & $\begin{array}{l}\text { Energy method that allows } \\
\text { quantitative measurements for } \\
\text { decision-making. }\end{array}$ \\
\hline $\begin{array}{l}\text { Definition of spatial limits in analysis } \\
\text { system. }\end{array}$ & $\begin{array}{l}\text { Definition of space-time limits in } \\
\text { analysis system. }\end{array}$ \\
\hline $\begin{array}{l}\text { Presents lower uncertainty. System } \\
\text { defined from direct objective of study } \\
\text { (mass and energy interactions). }\end{array}$ & $\begin{array}{l}\text { Presents greater uncertainty owing to } \\
\text { magnitude of study systems. System } \\
\text { extends from point of interest to } \\
\text { economic, social, and ecological } \\
\text { interaction of process. }\end{array}$ \\
\hline &
\end{tabular}

When analyzing the interdependence of energy and exergy, useful energy must be taken account. The exergy may be defined as that portion of the total energy of a system that is useful energy, whereas another portion of the energy is energy that is not available. The relation is expressed as

$$
E x n+E x=E n
$$


where Exn is energy not available, Ex is exergy, and En is total energy

From the above, an expression that relates the quantities of energy and exergy can be deduced:

$$
E x=\eta E n
$$

where $\eta$ is a coefficient that expresses the useful amount of total energy of the process.

Regarding to the emergy analysis, in previous studies ${ }^{58,59} \alpha$ (0.93) was defined as the factor that expresses the useful amount of energy in solar energy; from this factor, Bastianoni et al. ${ }^{58}$ derived the following expression:

$$
\frac{E m^{(E x)}}{\propto}=E m^{(E)}
$$

where $E m^{(E)}$ is emergy as a function of energy, and $E m^{(E x)}$ is emergy according to exergy.

Although it was shown that emergy is a function of exergy, in terms of methods of analysis of processes, exergy analysis can contribute to the emergy analysis to design or modify the process, according to the differences presented in Table 3 , where the mass and energy relations of the system can be studied directly within the surroundings. This allows increased energy efficiency (as in this study) or optimization of the process.

\section{Case study: Evaluation of sustainable use of biosolids generated in wastewater-treatment plant by emergy and exergy analysis}

Alternatives for using biosolids generated in a WWTP evaluated by Cano et al. ${ }^{1}$ were the generation of electricity by fluidized-bed gasification (an energy system) and as fertilizers for silvopastoral soils (an agricultural system). Emergy analysis was applied to these two systems for sustainability assessment using emergy indexes. The energy system alternative was the most sustainable according to emergy analysis, to which exergy analysis was applied. Destroyed exergy and global exergy efficiency per stage and per product of the respective stage were analyzed. Based on previously obtained results, we propose the use of energy streams previously considered to be notuseful by-products of the process, ultimately comparing the exergy efficiency and sustainability index of each stage.
Gasification, the thermochemical conversion of carbonaceous substrates (biosolids) into clean-fuel gas by using steam and air/ oxygen as gasifying agents, has the advantage of turning stabilized sludges into high-quality energy. ${ }^{21}$ This reduces the volume of biosolids, decreases emission of toxic organic compounds, and binds heavy metals in a solid matrix, thereby producing a clean-fuel gas ${ }^{1}$ (Appendix describes the stream mass flows and energy balances of the fluidized bed gasification process). This process is shown in Figure 1. First, the biosolids enter to the fluidized bed dryer to remove any remaining water. Then, the fluidized material passed into a mixing thank, where it is mixed with $10 \%$ coal in order to promote fluidization, improve its calorific value, and promote the occurrence of some beneficial thermal reactions in the fluidized bed. ${ }^{41,60}$ The biosolids are fed to the gasification reactor in conjunction with water and air. The produced ash during the gasification is collected and removed. Then, the gas goes through a heat exchanger to supply the energy demand from the fluidized bed dryer. The clean gas contains some tars that are removed using a cleaning fluid column whose fluid is a thermal oil. Finally, the synthesis gas is combusted in a gas turbine to generate electricity. Process energy and mass balance data were established from experimental values and simulation models of a gasification pilot plant located in the National University of Colombia.

To calculate the exergy of each stream present in the analysis system, the exergy contribution from ashes, tar, and heavy metals generated in the system were not considered. For the reference environment (where the equilibrium state is defined), it is assumed a temperature of $25^{\circ} \mathrm{C}$ and a pressure of $101.325 \mathrm{kPa}$.

\section{RESULTS AND DISCUSSION}

\section{Application of emergy analysis as tool for sustainability assessment of alternative uses}

Emergy analysis differentiates and separates the inputs from renewable, non-renewable, and imported sources. These distinctions make it possible to define emergy indexes, which provide valuable information for making sustainability decisions, especially when different alternatives are treated. . $20,61,62^{2}$

Tables 4 and 5 summary the percentage of renewable and imported resources that enter the gasification system and emergy indexes evaluated by Cano et al., ${ }^{1}$ assuming biosolids to be a renewable resource. The emergy indexes analyzed were the

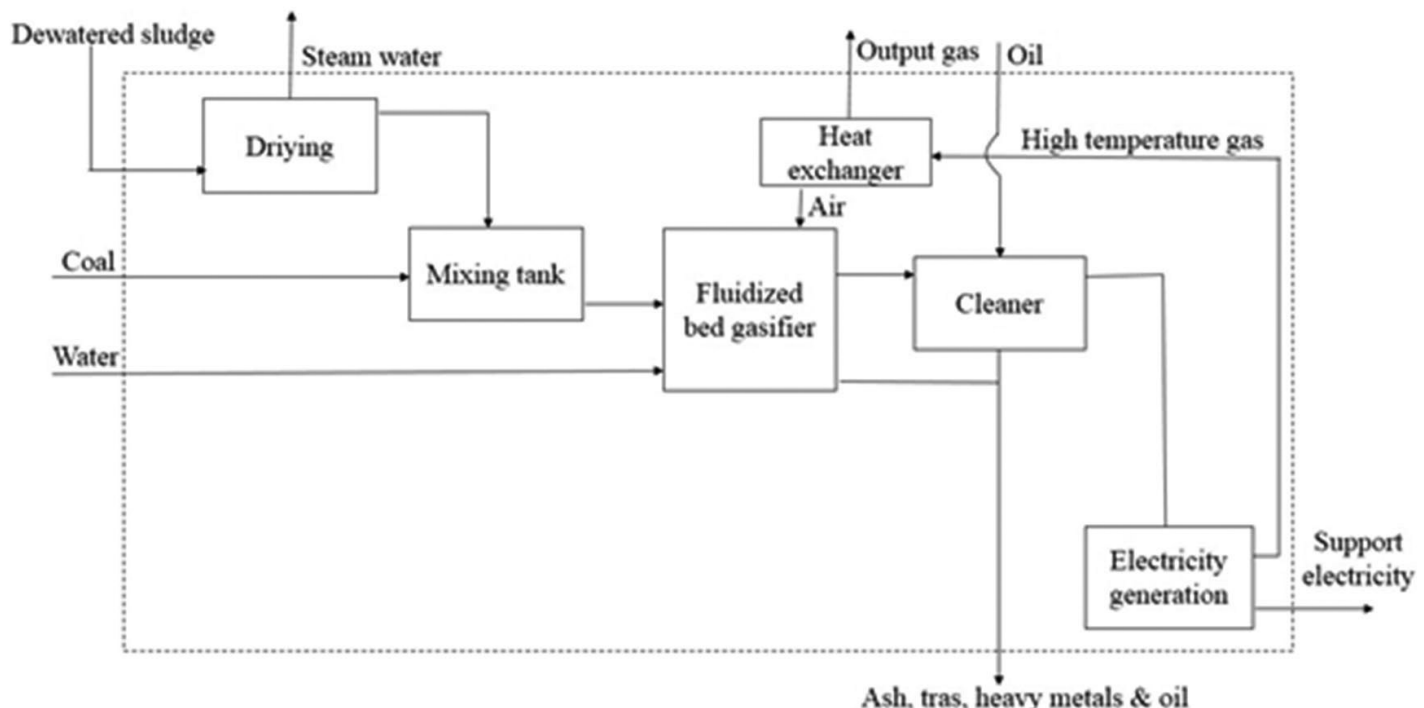

Figure 1. Summary diagram of use of biosolids for energy recovery through fluidized-bed-gasification process 
Table 4. Detail in emergy calculations

Emergy calculations: Use of biosolids for energy recovery by fluidized bed gasification. discretizing renewable. non-renewable and imported sources.

\begin{tabular}{|c|c|c|c|c|c|c|c|}
\hline & Item & Unit & $\begin{array}{c}\text { Data } \\
\text { (units/yr) }\end{array}$ & $\begin{array}{l}\text { Unit Solar } \\
\text { Emergy* } \\
\text { (seJ/unit) }\end{array}$ & $\begin{array}{c}\text { Solar } \\
\text { Emergy } \\
\text { (E13 seJ/yr) }\end{array}$ & $\begin{array}{c}\text { Em\$ } \\
\text { Value } \\
\text { (US\$/yr) }\end{array}$ & $\begin{array}{l}\text { Fraction } \\
\text { Emergy }\end{array}$ \\
\hline \multicolumn{8}{|c|}{ Renewable resources } \\
\hline 1 & Sun & $\mathrm{J}$ & $5.72 \mathrm{E}+13$ & 1 & 6 & 6.6 & \\
\hline 2 & Rain. chemical energy & $\mathrm{J}$ & $1.33 \mathrm{E}+11$ & $3.10 \mathrm{E}+04$ & 413 & 475.3 & 0.034 \\
\hline 3 & Wind. kinetic energy & $\mathrm{J}$ & $3.63 \mathrm{E}+08$ & $2.45 \mathrm{E}+03$ & 0.1 & 0.1 & 0.00001 \\
\hline 4 & Oxygen (in air) & $\mathrm{g}$ & $1.30 \mathrm{E}+07$ & $5.16 \mathrm{E}+07$ & 67 & 77.0 & 0.005 \\
\hline \multicolumn{8}{|c|}{ Non-renewable storages } \\
\hline 5 & Carbon & $\mathrm{J}$ & $3.28 \mathrm{E}+10$ & $3.92 \mathrm{E}+04$ & 129 & 147.8 & 0.010 \\
\hline 6 & ignition oil & $\mathrm{J}$ & $1.20 \mathrm{E}+09$ & $6.60 \mathrm{E}+04$ & 8 & 9.1 & 0.001 \\
\hline \multicolumn{8}{|c|}{ Purchased inputs } \\
\hline 7 & Fuel & $\mathrm{J}$ & $5.48 \mathrm{E}+10$ & $1.11 \mathrm{E}+05$ & 607 & 698.2 & 0.050 \\
\hline 8 & $\begin{array}{l}\text { Electricity (mixing. drying. } \\
\text { gasifying. gas cleaning) }\end{array}$ & $\mathrm{J}$ & $8.19 \mathrm{E}+09$ & $2.69 \mathrm{E}+05$ & 220 & 253.2 & 0.018 \\
\hline 9 & Machinery & $\mathrm{g}$ & $2.80 \mathrm{E}+06$ & $1.79 \mathrm{E}+10$ & 5004 & 5751.5 & 0.408 \\
\hline 10 & Biomass (from the sludge) & $\mathrm{g}$ & $2.00 \mathrm{E}+07$ & $2.70 \mathrm{E}+09$ & 5400 & 6206.9 & 0.441 \\
\hline 11 & Labor & $\mathrm{J}$ & $5.32 \mathrm{E}+08$ & $4.45 \mathrm{E}+06$ & 237 & 272.2 & 0.019 \\
\hline 12 & $\mathrm{H}_{2} \mathrm{O}$ & $\mathrm{g}$ & $3.83 \mathrm{E}+04$ & $6.64 \mathrm{E}+05$ & 3 & 2.9 & 0.000 \\
\hline \multirow[t]{2}{*}{13} & Disposal cost & US\$ & $1.93 \mathrm{E}+02$ & $8.70 \mathrm{E}+12$ & 168 & 193.0 & 0.014 \\
\hline & Total Emergy & & & & 12256 & 14087.1 & 1.000 \\
\hline \multicolumn{8}{|c|}{ Transformity. Calculated } \\
\hline \multirow[t]{15}{*}{$\overline{14}$} & Total Yield. Electricity & $\mathrm{kW}$ & 262336.59 & & & 72.871275 & \\
\hline & Transformity $(\mathrm{SeJ} / \mathrm{J})$ & & & $4.67 \mathrm{E}+08$ & & & \\
\hline & Emergy Money Ratio & $8.70 \mathrm{E}+12$ & & & & & \\
\hline & Electricity Sale price (US\$) & 14.5 & & & & & \\
\hline & NR & $\mathbf{R}$ & $\mathbf{F}$ & $\mathbf{Y}$ & Y (g. J. \$) & & \\
\hline & 137 & 481 & 11639 & 12256 & 14087.07 & & \\
\hline & 0.011 & 0.039 & 0.950 & 1 & & & \\
\hline & INDICES & & & & & & \\
\hline & $\begin{array}{l}\text { Environmental loading ratio. } \\
\text { ELR }\end{array}$ & 24.50 & & & & & \\
\hline & Emergy yield ratio. ELR & 1.05 & & & & & \\
\hline & $\begin{array}{l}\text { Emergy sustainability index. } \\
\text { ESI }\end{array}$ & 0.04 & & & & & \\
\hline & Emergy investment ratio. EIR & 18.86 & & & & & \\
\hline & $\%$ renewability ratio & 3.92 & & & & & \\
\hline & Soil emergy cost. SEC & 0.01 & & & & & \\
\hline & Emergy Exchange Ratio & 970.21 & & & & & \\
\hline \multirow[t]{8}{*}{1} & Sun & & & & & & \\
\hline & Insolation: & $7.52 \mathrm{E}+09$ & $\mathrm{~J} / \mathrm{m}^{2} / \mathrm{yr}$ & & & & \\
\hline & Area: & $1.00 \mathrm{E}+04$ & $\mathrm{~m}^{2}$ & & & & \\
\hline & Albedo: & 0.24 & Dimensionless & & & & \\
\hline & Conversion: & & (Avg. Total Anr & al Insolation & $\left.\mathrm{m}^{2} / \mathrm{yr}\right)($ Area $\mathrm{m}$ & 1-albedo) & \\
\hline & Annual energy: & $5.72 \mathrm{E}+13$ & $\mathrm{~J} / \mathrm{yr}$ & & & & \\
\hline & Emergy per unit input: & 1 & $\mathrm{seJ} / \mathrm{J}$ & & & & \\
\hline & Emergy Input: & $5.72 \mathrm{E}+13$ & $\mathrm{seJ} / \mathrm{yr}$ & & & & \\
\hline \multirow[t]{9}{*}{2} & Rain & & & & & & \\
\hline & Rainfall: & 2.7 & $\mathrm{~m} / \mathrm{yr}$ & & & & \\
\hline & Area: & 10000 & $\mathrm{~m}^{2}$ & & & & \\
\hline & Water density: & 1000000 & $\mathrm{~g} / \mathrm{m}^{3}$ & & & & \\
\hline & Water energy: & 4.94 & $\mathrm{~J} / \mathrm{g}$ & & & & \\
\hline & Conversion: & & (Rainfall $\mathrm{m} / \mathrm{yr})(\mathrm{Ar}$ & $\left.\mathrm{m}^{2}\right)($ Water & nsity $\left.\mathrm{g} / \mathrm{m}^{3}\right)(\mathrm{W}$ & r energy $\mathrm{J} / \mathrm{g}$ ) & \\
\hline & Annual energy: & $1.33 \mathrm{E}+11$ & $\mathrm{~J} / \mathrm{yr}$ & & & & \\
\hline & Emergy per unit input: & $3.10 \mathrm{E}+04$ & $\mathrm{seJ} / \mathrm{J}$ & & & & \\
\hline & Emergy Input: & $4.13 \mathrm{E}+15$ & $\mathrm{seJ} / \mathrm{yr}$ & & & & \\
\hline \multirow[t]{4}{*}{3} & Wind & & & & & & \\
\hline & Air density: & 1.3 & $\mathrm{~kg} / \mathrm{m}^{3}$ & & & & \\
\hline & $\begin{array}{l}\text { Annual average of wind } \\
\text { velocity: }\end{array}$ & 1.6 & $\mathrm{~m} / \mathrm{s}$ & & & & \\
\hline & Geotropic wind ( $60 \%$ of 1.6$)$ : & 0.96 & $\mathrm{~m} / \mathrm{s}$ & & & & \\
\hline
\end{tabular}


Table 4. Detail in emergy calculations (cont.)

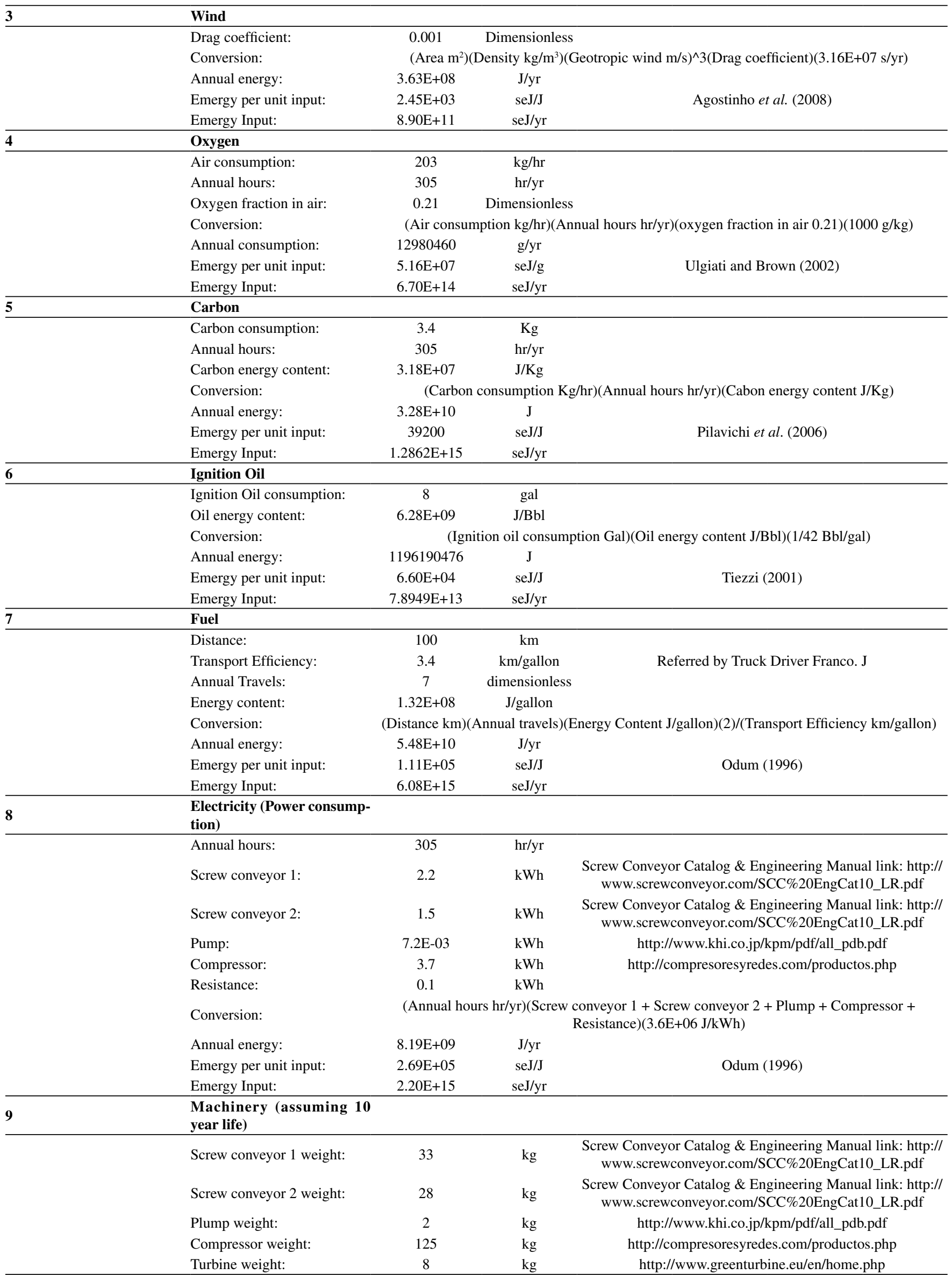


Table 4. Detail in emergy calculations (cont.)

\begin{tabular}{|c|c|c|c|c|}
\hline \multirow[t]{7}{*}{9} & \multicolumn{4}{|l|}{$\begin{array}{l}\text { Machinery (assuming } 10 \\
\text { year life) }\end{array}$} \\
\hline & Gasifier weight: & 2000 & $\mathrm{~kg}$ & \\
\hline & Others weight: & 600 & $\mathrm{~kg}$ & \\
\hline & Conversion: & & \multicolumn{2}{|c|}{ (All machinery weight summation) $(1000 \mathrm{~g} / \mathrm{kg})$} \\
\hline & Annual consumption: & 2795422 & $\mathrm{~g}$ & \\
\hline & Emergy per unit input: & $1.79 \mathrm{E}+10$ & $\mathrm{seJ} / \mathrm{g}$ & Brand W. (2002) \\
\hline & Emergy Input: & $5.00 \mathrm{E}+16$ & & \\
\hline \multirow[t]{7}{*}{10} & Sludge & & & \\
\hline & Sludge weight: & 20000 & $\mathrm{~kg}$ & \\
\hline & Biomass weight: & 20000 & $\mathrm{~kg}$ & \\
\hline & Conversion: & \multicolumn{3}{|c|}{ (Biomass weight $\mathrm{kg})(1000 \mathrm{~g} / \mathrm{kg})$} \\
\hline & Annual consumption: & $2.00 \mathrm{E}+07$ & $\mathrm{~J} / \mathrm{yr}$ & \\
\hline & Emergy per unit input: & $2.70 \mathrm{E}+09$ & $\mathrm{seJ} / \mathrm{J}$ & Xiao. H. et al. (2010) \\
\hline & Emergy Input: & $5.40 \mathrm{E}+16$ & $\mathrm{seJ} / \mathrm{yr}$ & \\
\hline \multirow[t]{7}{*}{11} & Labor. J & & & \\
\hline & Human energy consumption: & 436 & $\mathrm{KJ} / \mathrm{hr}$ & FAECM data in Fluck (1992) \\
\hline & Worked hours: & 1220 & $\mathrm{hrs} / \mathrm{yr}$ & \\
\hline & Conversion: & \multicolumn{3}{|c|}{ (Human energy consumption $\mathrm{kJ} / \mathrm{hr}$ )(Worked hours $\mathrm{hr} / \mathrm{yr})(1000 \mathrm{~J} / \mathrm{kJ})$} \\
\hline & Annual energy: & $5.32 \mathrm{E}+08$ & $\mathrm{~g} / \mathrm{yr}$ & \\
\hline & Emergy per unit input: & $4.45 \mathrm{E}+06$ & $\mathrm{seJ} / \mathrm{g}$ & Brand W. (2002) \\
\hline & Emergy Input: & $2.37 \mathrm{E}+15$ & $\mathrm{seJ} / \mathrm{yr}$ & \\
\hline \multirow[t]{7}{*}{12} & $\mathbf{H}_{2} \mathbf{O}$ & & & \\
\hline & $\mathrm{H}_{2} \mathrm{O}$ consumption: & 0.13 & $\mathrm{~kg} / \mathrm{hr}$ & \\
\hline & Annual hours: & 305 & $\mathrm{hr} / \mathrm{yr}$ & \\
\hline & Conversion: & \multicolumn{3}{|c|}{$\left(\mathrm{H}_{2} \mathrm{O}\right.$ consumption $\left.\mathrm{kg} / \mathrm{hr}\right)($ Annual hours $\mathrm{hr} / \mathrm{yr})(1000 \mathrm{~g} / \mathrm{kg})$} \\
\hline & Annual consumption: & 38336 & $\mathrm{~g} / \mathrm{yr}$ & \\
\hline & Emergy per unit input: & $6.64 \mathrm{E}+05$ & $\mathrm{seJ} / \mathrm{g}$ & Bargigl et al. (2010) \\
\hline & Emergy Input: & $2.55 \mathrm{E}+13$ & $\mathrm{seJ} / \mathrm{yr}$ & \\
\hline \multirow[t]{7}{*}{13} & Ash Disposal Cost & & & \\
\hline & Ashes: & 53 & US\$ & Raskin and Ensley (2000) \\
\hline & $\begin{array}{l}\text { Ash disposal cost }+ \text { tar }+ \text { heavy } \\
\text { metals: }\end{array}$ & 125 & US\$ & Raskin and Ensley (2000) \\
\hline & Oil disposal cost: & 15 & US\$ & Raskin and Ensley (2000) \\
\hline & Total Cost: & 193 & US\$ & \\
\hline & Emergy Money Ratio: & $8.70 \mathrm{E}+12$ & seJ/ US\$ & Odum (1996) \\
\hline & Emergy Input: & $1.6791 \mathrm{E}+15$ & $\mathrm{seJ} / \mathrm{yr}$ & \\
\hline
\end{tabular}

Table 5. Percentage of non-renewable (NR), renewable (R), and imported (F) resources and total process emergy

\begin{tabular}{ccccc}
\hline & NR $(\%)$ & R $(\%)$ & F (\%) & $\begin{array}{c}\text { Total Emergy } \\
(\text { SeJ/year })\end{array}$ \\
\hline Gasification & 1.1 & 48 & 50.9 & $12.256 \times 10^{13}$ \\
\hline
\end{tabular}

Table 6. Emergy indexes assuming biosolids to be renewable and imported resource. (ELR, environmental-loading ratio; EYR, emergy-yield ratio; ESI, emergy sustainability index)

\begin{tabular}{cccc}
\hline & ELR & EYR & ESI \\
\hline Interval Optimum & $2-10$ & $2-5$ & $1-5$ \\
Gasification System & 1.08 & 1.96 & 1.81 \\
\hline
\end{tabular}

Environmental-Loading Ratio, Emergy-Yield Ratio, Emergy Sustainability Index (Table 6). Table 4 shows in detail the emergy calculations.

A productive process is sustainable when presents the highest economic profit with lowest environmental load through optimization of the process; that is, by the reduction of the exergy destroyed due to the process irreversibilities and/or technology improving. Based on this, gasification system exhibit a sustainability, which is very close to the lower limit (1-5) with a value of 1.81 ; that is, the process is sustainable in the medium term but not assured in the long term. ${ }^{1}$ Despite of gasification system has a low environmental impact $($ ELR $<2)$, the amount of primary resources used is not considerable; that is to say, it is necessary a large contribution (52\%) of nonrenewable resources processed (secondary resources).

\section{Application of exergy analysis for energy recovery from biosolids generated in wastewater-treatment plant}

Table 7 presents the exergy values of the streams involved in the process, as well as the exergy destroyed. Exergy indexes resulting from the global gasification process are presented in Table 8 . Appendix explains in detail the exergy calculations.

The renewability index quantifies the system's dependence on renewable resources. The influence of biosolids as renewable resources is notable, this being the main renewable input in the process, with a value of 0.55 .

The sustainability index relates the environmental impact and sustainability of the process with respect to exergy efficiency. The overall process has a low exergy efficiency (0.015), while a sustainability index close to unity (1.015) represents a significant effect on the environment. From the results obtained in the global 
Table 7. Exergy balance of use of biosolids for energy recovery by fluidizedbed gasification (inlet and outlet streams)

\begin{tabular}{lc}
\hline Stream & Exergy flow $[\mathrm{kW}]$ \\
\hline Biomass input (dewatered sludge) & 199.63 \\
Coal inlet & 21.29 \\
Air inlet & 0 \\
Water inlet & 0.02 \\
Cleaner inlet (isopropanol) & 11.23 \\
Work & 128.8 \\
Steam outlet from dryer & 4.84 \\
Gas output & 0.36 \\
Electricity & 0.24 \\
Ash, tar, heavy metals, and oil & 0 \\
DESTROYED EXERGY & 355.54 \\
\hline
\end{tabular}

Table 8. Exergy indexes of global energy recovery process by fluidized-bed gasification

\begin{tabular}{cccc}
\hline $\begin{array}{c}\text { Alternative use of } \\
\text { biosolids }\end{array}$ & $\begin{array}{c}\text { Renewability } \\
\text { index }\end{array}$ & $\begin{array}{c}\text { Sustainability } \\
\text { index }\end{array}$ & Exergy efficiency \\
\hline Gasification & 0.55 & 1.015 & 0.015 \\
\hline
\end{tabular}

process, it is necessary to analyze each component to identify those stages amenable to possible improvements due to usable energy potential.

\section{Exergy indexes by process component}

Table 9 shows exergy analysis results by component of each stage supply chain of the energy recovery process by fluidizedbed gasification: input exergy, output exergy, destroyed exergy, sustainability index, and exergy efficiency.

Table 9. Exergy indexes by component for each process stage in energy recovery by fluidized-bed gasification

\begin{tabular}{lccccc}
\hline Stage & $\begin{array}{c}\text { Input } \\
\text { exergy } \\
(\mathrm{kW})\end{array}$ & $\begin{array}{c}\text { Output } \\
\text { exergy } \\
(\mathrm{kW})\end{array}$ & $\begin{array}{c}\text { Destroyed } \\
\text { exergy } \\
(\mathrm{kW})\end{array}$ & $\begin{array}{c}\text { Sustainability } \\
\text { index }\end{array}$ & $\begin{array}{c}\text { Exergy } \\
\text { efficiency }\end{array}$ \\
\hline $\begin{array}{l}\text { Fluidized-bed } \\
\text { dryer }\end{array}$ & 330.38 & 230.25 & 100.14 & 3.30 & 0.70 \\
Mixing tank & 246.41 & 244.54 & 1.87 & 131.97 & 0.99 \\
Gasifier & 244.83 & 237.39 & 7.44 & 32.87 & 0.97 \\
Ash remover & 237.39 & 213.06 & 24.33 & 9.76 & 0.90 \\
Recuperator 1 & 213.27 & 207.2 & 6.06 & 35.19 & 0.97 \\
Cleaner & 318.02 & 128.35 & 189.67 & 1.68 & 0.40 \\
Turbine & 8.16 & 1.39 & 6.77 & 1.21 & 0.17 \\
Recuperator 2 & 1.15 & 1.02 & 0.14 & 8.53 & 0.88 \\
Recuperator 3 & 0.98 & 0.83 & 0.16 & 6.21 & 0.84 \\
\hline
\end{tabular}

Although there is a share of $6 \%$ in relation to the exergy contribution of coal relating to the global process exergy, it shows how process stages with greater efficiency present the highest index of exergy sustainability. This is the case for the mixing stage, which has the highest index in terms of usable energy with a value of 0.99 and a sustainability index of 131.97 , evidenced the lowest exergy destroyed regarding to the process input. The mixing process, presenting a lower amount of irreversibilities, shows a high value of sustainability index. This index must be interpreted based on the amount of exergy destroyed produced, which at the end of the process becomes a measure of the impact on the environment. In this way, the mixing process has a zero impact at the environmental level. Unlike power-generation (turbine) and gas-cleaning stages, for which exergy efficiencies are 0.17 and 0.4 , respectively. Those stages are of interest in terms of improvements, representing the most-efficient energy recovery process. This does not imply that improvements can be made by using new technologies and/or the waste streams with high energy potentials.

Table 10. Exergy efficiency of each product during stages of energy recovery process by fluidized-bed gasification. $\left[\beta_{\mathrm{i}}\right.$, exergy efficiency; numbers in parentheses refer to streams (Cano et al.) (Appendix)]

\begin{tabular}{lcc}
\hline Stage & Product (stream) & $\beta_{\mathrm{i}}$ \\
\hline Fluidized-bed dryer & Steam (2) & 0.02 \\
& Dehydrated sludge (3) & 0.68 \\
\hline Mixing tank & Mixture (5) & 0.99 \\
\hline Gasifier & Gas (7) & 0.97 \\
\hline Ash remover & Gas (8) & 0.90 \\
\hline \multirow{2}{*}{ Recuperator 1 } & Hot air (31) & 0.01 \\
& Gas (16) & 0.97 \\
Cleaner & Gas (22) & 0.03 \\
& Waste oil (18) & 0.38 \\
Turbine & Gas (27) & 0.14 \\
\hline \multirow{2}{*}{ Recuperator 2 } & Work (26) & 0.03 \\
\hline \multirow{2}{*}{ Recuperator 3 } & Gas (43) & 0.73 \\
& Air (6) & 0.16 \\
\hline
\end{tabular}

As mentioned above, in power-generation (turbine) and gascleaning stages, changes can be proposed to improve overall efficiency of the process. However, the exergy efficiency of each product $\left(\beta_{\mathrm{i}}\right)$ as it is exhibited in Table 10, the relation between exergy of the analyzed product and total input exergy, indicates the fraction of available exergy used by the stream of interest.

Exergy efficiency of each product $\left(\beta_{\mathrm{i}}\right)$ shows how the powergeneration (turbine) energy stage is limited to technological improvements, unlike the second stage mentioned, where implementation of new technologies is factored in, energy use of the waste oil stream, whose efficiency value $\left(\beta_{i}=0.38\right)$ is quite close to the efficiency of the respective stage (0.4), can be given, implying that coproducts streams may have a useful energy content higher than the main stream of the stage. That is why it is necessary to give an added energy value to secondary streams within the global process. Among the uses of added energy value within the process that can be applied to this stream is that of burning for use in motor generators or as a fuel precursor. ${ }^{63}$ It is also recommended not to let tar accumulate for a quick reuse of oil, which is achieved with cleaning technologies such as electrostatic precipitators..$^{64,65}$

\section{CONCLUSIONS}

Emergy analysis allows the choice of the most sustainable among different alternatives for using biosolids generated in a WWTP, resulting in the choice of gasification process for energy recovery considering all the resources involved in the process and the biosphere as the frontier of analysis. With the exergy analysis, the most-efficient way from the energy point of view is evaluated according to how well the chosen alternative would work. Exergy analysis notably differs by 
its limitation of analysis being subject to the object of study, where only direct inputs can be processed and impacts that can be considered are only those associated with the products obtained. Accordingly, we complemented emergy and exergy analyses - the first for the choice of the most sustainable process in terms of the efficient use of resources (natural capital); and the second for the most-efficient way to develop the process through the account of the energy available destroyed as one of the negative effects relate to the resources demand, which allow to associate the load with the generation of energy wasted but allows energy optimization of the process.

Based on the analysis conducted, the more environmentally sustainable stage of the process, in terms of exergy analysis, was revealed to be by mixing biosolids with carbon. As expected, this process has the highest exergy sustainability index (137.02) due to the low ratio between destroyed exergy and total input exergy. When comparing this stage with the one with the lowest exergy sustainability index (1.21) (turbine), there is a notable difference between exergy efficiency values, 0.99 and 0.17 , respectively. Clearly, although there are stages of the process with a greater flow of exergy destroyed, as in the case of the ash remover, they have higher sustainability indexes because that index is a function of both exergy destroyed and of the relation between exergy streams involved in stages of the process. This behavior is normal given that, apart from the advantage offered by the mixture of biosolids with coal (10\%), an improvement in the calorific power of the resource is achieved, with an exergy supply of $6 \%$ of coal to the global process.

Energy-transformation (turbine) and gas-cleaning stages, with an exergy efficiencies equal to 0.17 and 0.4 , respectively, are considered of interest as processes characterized by improved energy recovery and greater efficiency and in terms of new technologies and/or use of waste streams with high energy potentials.

\section{SUPPLEMENTARY MATERIAL}

Supplementary material is available at http://quimicanova.sbq. org.br, as a free access PDF file.

\section{REFERENCES}

1. Londoño, N.A.C.; Suárez, D. G.; Velásquez, H. I.; Ruiz-Mercado, G. J.; J. Cleaner Prod. 2017, 141, 182.

2. E.S.P.; Informe de análisis físico-químico, Planta de Tratamiento de Aguas Residuales de Biosólidos San Fernando, Empresas Públicas de Medellín, 2020.

3. Aznar, M. P.; Caballero, M. A.; Gil, J.; Martin, J. A.; Corella, J.; Ind. Eng. Chem. Res. 1998, 37, 2668.

4. Mathieu, P.; Dubuisson, R.; Energy Procedia 2002, 43, 1291.

5. Staf, M.; Buryan, P.; Chem. Pap. 2016, 70, 479.

6. Guven, H.; Ersahin, E.; Dereli, R.; K.; Ozgun H.; Isik, I.; Ozturk, I.; Energy 2019, 172, 1027.

7. Akyol, Ç.; Foglia, A.; Ozbayram, E. G.; Frison, N.; Katsou, E.; Eusebi, A. L.; Fatone, F.; Crit. Rev. Environ. Sci. Technol. 2020, 50, 869.

8. Wang, R.; Wang, C.; Zhao, Z.; Jia, J.; Jin, Q.; Energies 2019, 186, 115848.

9. López-Ridaura, S.; Masera, O.; Astier, M.; Ecol. Indic. 2002, 2, 135.

10. Rosen, M. A.; Dincer, I.; Kanoglu, M.; Energy Policy 2008, 36, 128.

11. Dincer, I.; Rosen, M. A.; Exergy: energy, environment and sustainable development, Newnes, 2012.

12. Kharrazi, A.; Kraines, S.; Hoang, L.; Yarime, M.; Ecol. Indic. 2014, 37, 81.

13. Krahl, I. M. P.; VI Congresso Nacional de Excelência em Gestão, Niterói $-\mathrm{RJ}, 2010$

14. Niembro, I. J.; González, M. M.; Congreso Nacional del Medio
Ambiente, Cumbre del Desarrollo Sostenible, 2009.

15. Wang, S.; Liu, C.; Liu, C.; Zhang, C.; Liu, L.; Xiu, X.; J. Cleaner Prod. 2019, 218,543

16. Mascarenhas, J. dos S.; Chowdhury, H.; Thirugnanasambandam, M.; Chowdhury, T.; Saidur, R. J. J.; J. Cleaner Prod. 2019, 231, 183.

17. Karimi, M.; J. Cleaner Prod. 2017, 141, 50.

18. Compton, M.; Rezaie, B. J. E.; Energy 2017, 119, 257.

19. Chowdhury, T.; Chowdhury, H.; Chowdhury, P.; Sait, S. M.; Paul, A.; Ahamed, J. U.; Saidur, R.; J. Therm. Anal. Calorim. 2020, 37, 100615.

20. Odum, H. T.; Environmental accounting: emergy and environmental decision making, Wiley New York, 1996.

21. Brown, M. T.; Ulgiati, J. E. M.; Ecol. Indic. 2010, 221, 2501.

22. Wang, H.; Brown, S. L.; Magesan, G. N.; Slade, A. H.; Quintern, M.; Clinton, P. W.; Payn, T. W.; Environ. Sci. Pollut. Res. 2008, 15, 308.

23. Ocaña, V.; Dewulf, J.; Quintana, C.; Van Langenhove, H.; Roque, P.; UTC CIENCIA 2006.

24. Meillaud, F.; Gay, J.-B.; Brown, M.; Solar Energy 2005, 79, 204.

25. Björklund, J.; Geber, U.; Rydberg, T.; Resour., Conserv. Recycl. 2001, $31,293$.

26. Siracusa, G.; La Rosa, A. D.; Ecol. Modell. 2006, 197, 490.

27. Hellström, D.; Water Environ. Res. 1997, 69, 44.

28. Fitzsimons, L.; Horrigan, M.; McNamara, G.; Doherty, E.; Phelan, T.; Corcoran, B.; Clifford, E.; J. Cleaner Prod. 2016, 131, 387.

29. Shao, L.; Chen, G.; Ecol. Indic. 2015, 58, 392.

30. Ozdil, N. F. T.; Tantekin, A.; Open Renewable Energy J. 2016, 97, 90.

31. Mora, C.; de Oliveira Jr, S.; Reterm engenharia termica 2006, 5, 24

32. Gallegos, A.; Zaleta, A.; Gónzalez, B.; Int. J. Thermodyn. 2003, 6, 169.

33. Bastianoni, S.; Pulselli, F. M.; Rustici, M.; Ecol. Indic. 2006, 6, 58.

34. Hovelius, K.; Wall, G.; Ecol. Indic. 1998, 98, 8.

35. Sciubba, E.; Ulgiati, S.; Energy 2005, 30, 1953.

36. Liao, W.; Heijungs, R.; Huppes, G.; Open Renewable Energy J. 2011, 36, 3479.

37. Patten, B. C.; Ecol. Modell. 1995, 79, 75.

38. Stillwell, A. S.; Hoppock, D. C.; Webber, M. E.; Sustainability 2010, 2 , 945.

39. Midilli, A.; Dogru, M.; Howarth, C. R.; Ling, M. J.; Ayhan, T.; Energy Convers. Manage. 2001, 42, 157.

40. Groß, B.; Eder, C.; Grziwa, P.; Horst, J.; Kimmerle, K. J. W. M.; Nucl. Chem. Waste Manage. 2008, 28, 1819.

41. Schowanek, D.; Carr, R.; David, H.; Douben, P.; Hall, J.; Kirchmann, H.; Webb, S.; Regul. Toxicol. Pharmacol. 2004, 40, 227.

42. Muniesa Bastida, B.; Tesis de pregrado, Escola Tècnica Superior d'Enginyeria Industrial de Barcelona, España, 2005.

43. Londoño, N. A. C.; Velásquez, H. I.; McIntyre, N.; Ecol. Indic. 2019, 107, 105600.

44. Álvarez, S.; Lomas, P.; Martín-López, B.; Rodríguez, M.; Montes, C. J.; Publicaciones de la Fundación Fernando González Bernáldez 2005, 2.

45. Brandt-Williams, S. L.; Handbook of Emergy Evaluation, University of Florida, U. S. A., 2002.

46. Cao, K.; Feng, X. J. P. S.; Protection, E.; The emergy analysis of multiproduct systems, 2007, vol. 85, 494.

47. Brown, M. T.; Raugei, M.; Ulgiati, S.; Ecol. Indic. 2012, 15, 227

48. Zhang, X.-H.; Wei, Y.; Li, M.; Deng, S.-H.; Wu, J.; Zhang, Y.-Z.; Xiao, H.; Resour., Conserv. Recycl. 2014, 92, 95.

49. Cengel, Y. A.; Boles, M. A.; Termodinámica, $8^{\text {a }}$ ed., McGraw Hill: Mexico, 2015.

50. Hau, J. L.; Bakshi, B. R.; Environ. Sci. Technol. 2004, 38, 3768.

51. Moran, M.; Shapiro, H. J. B.; Fundamentos de termodinámica técnica, 2nd ed., Reverté: Barcelona, 2012

52. Ptasinski, K. J.; Prins, M. J.; Pierik, A.; Energy 2007, 32, 568.

53. Szargut, J.; Morris, D. R.; Steward, F. R.; Exergy Analysis of Thermal, Chemical, and Metallurgical Processes, 1988, 7.

54. Hepbasli, A.; Utlu, Z.; Akdeniz, R. C.; Energy Policy 2007, 35, 3015. 
55. Reyes, J. G.; Caldera de Biomasa, Bachelor, Departamento Ingeniería de la Construcción y Proyectos de Ingeniería, Universidad de Sevilla, 2016.

56. Ojeda, K. A.; Tesis presentada en opción al grado científico de Doctor en Ingeniería Química, Universidad Industrial de Santander, Bucaramanga, 2011.

57. Ludovisi, A.; Poletti, A.; Ecol. Modell. 2003, 159, 223.

58. Weidou, N.; Johansson, T. B.; Energy Policy 2004, 32, 1225.

59. Bastianoni, S.; Facchini, A.; Susani, L.; Tiezzi, E. J. E.; Energy Policy 2007, 32, 1158.
60. Wall, G.; Gong, M.; Exergy 2001, 1, 128.

61. Almeida, C.; Rodrigues, A.; Bonilla, S.; Giannetti, B. J.; J. Cleaner Prod. 2010, 18, 32.

62. Smith, R. L.; Ruiz-Mercado, G. J.; Clean technologies and environmental policy 2014, 16, 749.

63. Cohen, M. J.; Brown, M. T.; Shepherd, K. D.; Agric., Ecosyst. Environ. 2006, 114, 249.

64. IDAES; BESEL; Biomasa: Gasificación, Madrid, España, Departamento de Energía, 2007.

65. Navarro, L.; Hosnar, D.; Tesis de pregrado, Perú, 2018. 